\title{
Carbonization of a radicular cyst using fiber-optic diode laser: a case
} report

\author{
Panagiotis Kafas*1 and Sotirios Kalfas ${ }^{2}$
}

\author{
Address: ${ }^{1}$ Department of Oral Surgery, School of Dentistry, Aristotle University, Thessalonica, Greece and ${ }^{2}$ Department of Preventive Dentistry, \\ School of Dentistry, Aristotle University, Thessalonica, Greece \\ Email: Panagiotis Kafas* - pankafas@yahoo.com; Sotirios Kalfas - kalfas@dent.auth.gr \\ * Corresponding author
}

Published: 19 August 2008

Cases Journal 2008, I:II3 doi:10.1186/1757-1626-1-113

This article is available from: http://www.casesjournal.com/content/l/I/II3

(c) 2008 Kafas and Kalfas; licensee BioMed Central Ltd.

This is an Open Access article distributed under the terms of the Creative Commons Attribution License (http://creativecommons.org/licenses/by/2.0), which permits unrestricted use, distribution, and reproduction in any medium, provided the original work is properly cited.
Received: II August 2008

Accepted: 19 August 2008

\begin{abstract}
A female patient, 5 I years old, complaint of painful swelling on the anatomical area of the upper left lateral incisor. The diagnosis of radicular cyst was confirmed histo-pathologically. Nowadays, radicular cysts may be treated using conventional root canal methods or surgical apicectomy. The possible soft-laser reaction to radicular cysts after contact application has not been investigated. We present an in vitro case of a diagnosed radicular cyst which carbonized after contact application of diode laser. The need for future clinical trials will be essential to prove the sensitivity of this procedure in humans.
\end{abstract}

\section{Case report}

A Caucasian female patient, 51 years old presented to the clinic with swelling of the anterior upper jaw. The patient was working is store house. She was smoking 20 cigarettes per day for 20 years. She was drinking alcohol occasionally. The medical history revealed previous surgical procedure for appendicectomy. The dental history was free apart from routine dental procedures such as fillings and prosthetics. The patient was $58 \mathrm{~kg}$ weight and $167 \mathrm{~cm}$ height. The clinical and radiographic examination revealed a periapical lesion of the upper left lateral incisor.

It was decided to extract the tooth which was severely decayed and non restorable. The upper left incisor was extracted with the associated periapical lesion. The tooth with the soft-tissue lesion was stored in buffered formalin for 24 hours and decalcified. The decalcification was carried out to cut the tooth longitudinally. This allowed the processing of specimens for their diagnostic microscopic evaluation. The pathological examination showed the atrophic epithelial lining of radicular cyst.
The second tooth and cyst portion was used for evaluation of laser performance. The laser parameters used were 1500 $\mathrm{mW}$ of continuous output in $808 \mathrm{~nm}$ wavelength. The fiber optic had a diameter of $300 \mu \mathrm{m}$. The cyst was stained using methylene blue for observation (Figure. 1). The fiber-optic diode laser passed through the bisected root canal into the radicular cyst (Figure. 2). The cyst carbonized in about 30 seconds after constant contact. It was obvious that the destruction of radicular cysts may be carried out with laser techniques. Theoretically, this will allow rapid healing if it is associated with endodontic treatment.

\section{Discussion}

Radicular cysts are the most common inflammatory tooth-associated cystic lesions [1]. Their treatment is mainly based on lege artis endodontic treatment or surgical excision of the cyst lining with apicectomy [2,3]. These two well established procedures are considered the golden standards for the management of such lesions. 


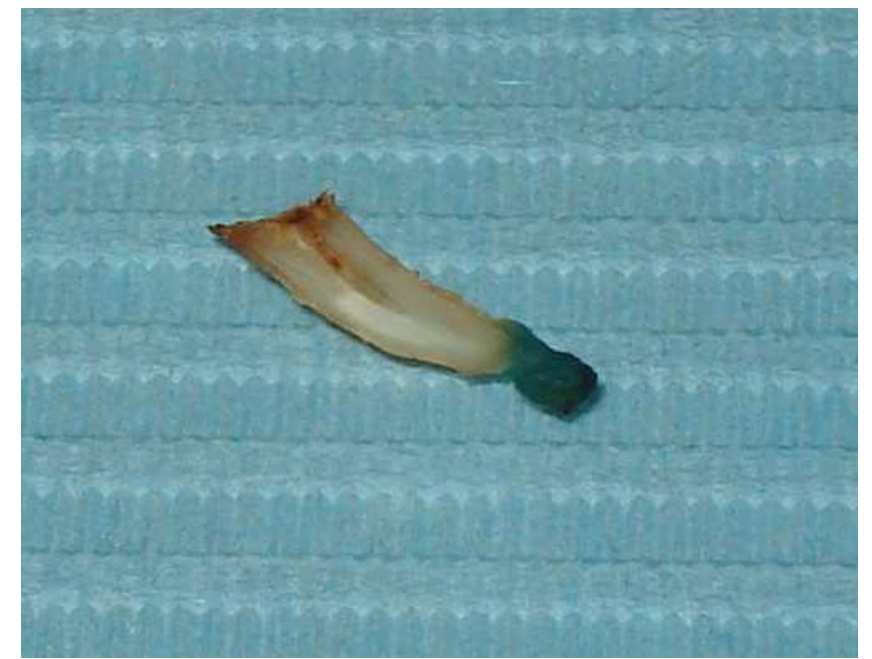

\section{Figure I}

Radicular cyst size was observed using methylene blue staining.

A diode laser causes warming, welding, coagulation, protein denaturization, drying, vaporization, and carbonization of the target tissue [4]. Diode-laser treatment of targeted periapical lesions has not been used in the past.

The reason for the skepticism about this procedure may be associated to the complete digestion of carbonized prod-

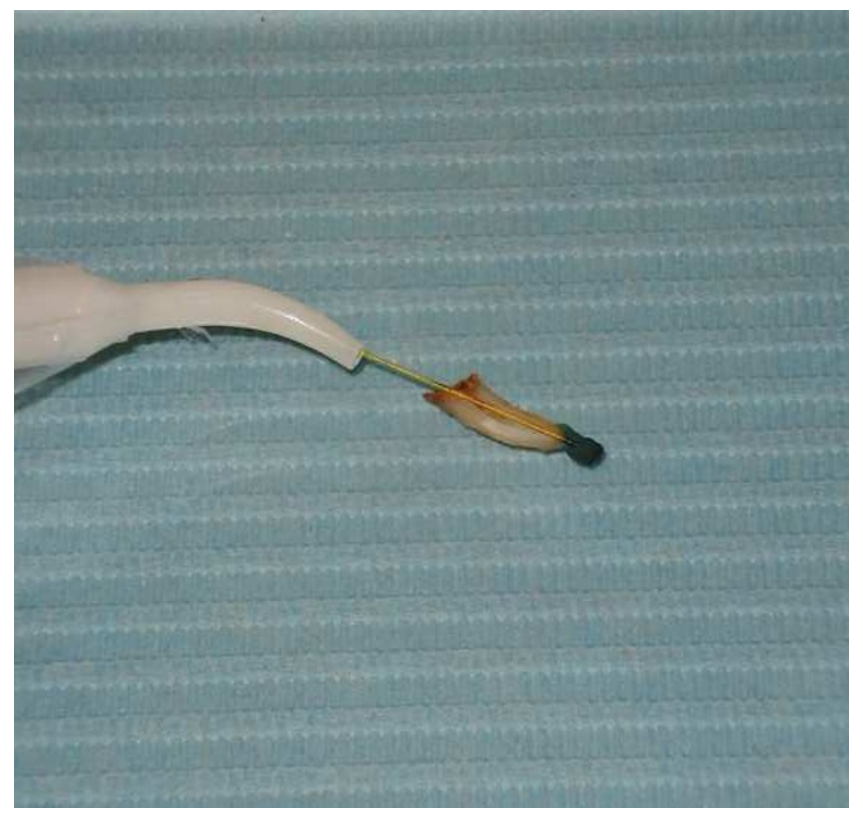

Figure 2

Fiber-optic passed through the bisected root canal into the cystic cavity. ucts (Figure. 3). According to previous reports, carbonized tissues are digested by giant cells or macrophages [5].

Diode-laser carbonization of radicular cysts may be effective using fiber-optic technology. The only prerequisite is the measurement of the tooth length for correctly placing the fiber through the root canal into the cystic cavity. Hypothetically, the limitations to the application of this technique maybe the impaired defense mechanism, the smoke released in the closed cavity, the vital adjacent tissues (air sinuses, nerves, vessels) and the burning of bone. Considering, that the root is mechanically open during endodontic treatment the use of micro-suction tips may be found useful in releasing the generated smoke out of the cystic cavity. Diode laser is soft light energy, therefore the expected damage of the surrounding bone should be considered minimal.

Future research need to be carried out to assess the effectiveness of this procedure in clinical trials. Possibly another cost-effective tool may be added to the armamentarium of the dentists for future applications.

\section{Conclusion}

While this technique may have some applications as a possible new technique the research needs to be exhaustive. We are already aware of the capabilities of small fibre laser and the effect of lasers on soft tissues but the effect of lasers used in an enclosed space in living bone is of interest. To be taken further it would presumably need rigorous testing on animals.

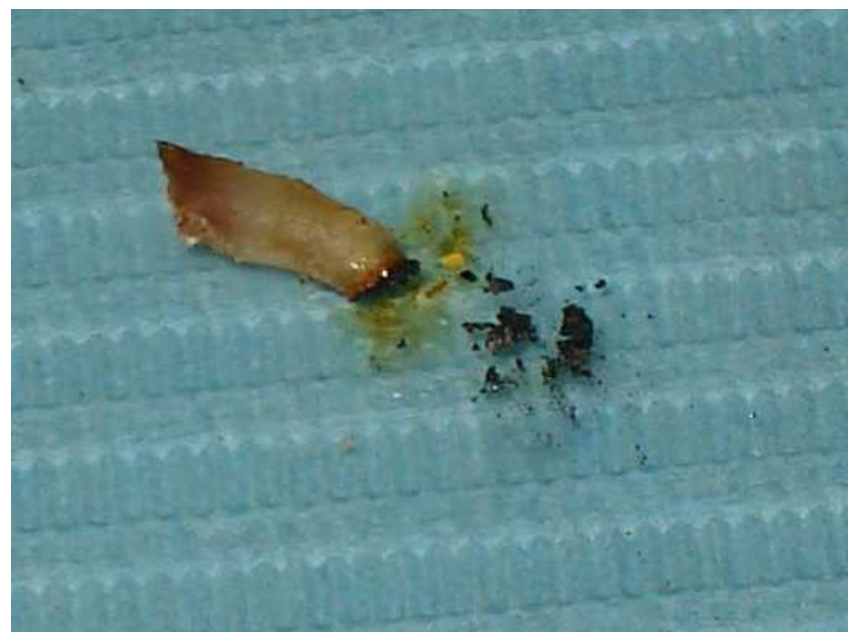

Figure 3

Carbonization of radicular cyst was performed in a few seconds. 


\section{Consent}

"Written informed consent was obtained from the patient for publication of this case report and accompanying images. A copy of the written consent is available for review by the Editor-in-Chief of this journal."

\section{Competing interests}

The authors declare that they have no competing interests.

\section{Authors' contributions}

SK analyzed and interpreted the patient data regarding radicular cyst. PK performed the histological examination of the cyst, and was major contributor in performing the laser experiment and writing the manuscript. All authors read and approved the final manuscript.

\section{References}

I. Soames JV, Southam JC: Cysts of the jaws and oral soft tissues. In Oral Pathology 3rd edition. Edited by: Soames JV, Southam JC. Oxford: Oxford University Press; 1999:73-92.

2. Garcia CC, Sempere FV, Diago MP, Bowen EM: The post-endodontic periapical lesion: histologic and etiopathogenic aspects. Med Oral Patol Oral Cir Bucal 2007, I 2:E585-590.

3. Komori T, Yokoyama K, Takato T, Matsumoto K: Clinical application of the erbium: YAG laser for apicoectomy. J Endod 1997, 23:748-750.

4. Sarver DM, Yanosky M: Principles of cosmetic dentistry in orthodontics: Part 2. Soft tissue laser technology and cosmetic gingival contouring. Am J Orthod Dentofac Orthoped 2005, 1 27:85-90

5. Williams TM, Cobb CM, Rapley JW, Killoy WJ: Histologic evaluation of alveolar bone following $\mathrm{CO} 2$ laser removal of connective tissue from periodontal defects. Int J Periodontics Restorative Dent 1995, 15:497-506.
Publish with Bio Med Central and every scientist can read your work free of charge

"BioMed Central will be the most significant development for disseminating the results of biomedical research in our lifetime. "

Sir Paul Nurse, Cancer Research UK

Your research papers will be:

- available free of charge to the entire biomedical community

- peer reviewed and published immediately upon acceptance

- cited in PubMed and archived on PubMed Central

- yours - you keep the copyright

Submit your manuscript here:

http://www.biomedcentral.com/info/publishing_adv.asp 